\title{
Geothermal Potential of Sedimentary Basins, especially of the Swiss Molasse Basin
}

\author{
RYBACH, Ladislaus \\ Institute of Geophysics, ETH Zurich, Sonneggstrasse 5, CH-8092 Zurich, Switzerland. \\ E-mail: rybach@ig.erdw.ethz.ch
}

\section{Üledékes medencék geotermikus potenciálja, különös tekintettel a svájci Molasse-medencére}

Összefoglaló

Az üledékes medencék általában jelentős geotermikus potenciállal rendelkeznek, különösen ha mély vízadó képződmények vannak jelen. A geotermikus potenciál nagysága függvénye a medencealkotó folyamatoknak, mint az üledékképződés, karsztosodás, törésfejlődés; míg hasznosítás szempontjából a készletjellemzők (porozitás, permeabilitás; mélység, ill. hőmérséklet) és a termelés fenntarthatósága meghatározó. Jelen tanulmány az utóbbi tulajdonságokra fókuszál az Amerikai Egyesült Államok medencéi, a Párizsi-medence, a Pannon-medence és a Molasse-medence példáján. Először a Molassemedence francia, német és osztrák részeit tárgyalom, majd a svájci Molasse-medence (SMB) részletes bemutatása következik.

A cikk ismerteti az eddigi erőfeszítéseket a SMB geotermikus potenciáljának meghatározását illetően néhány eredménytérkép közlésével. Az SMB potenciáljának eddigi kiaknázása eddig nem volt nagyon eredményes, tíz mélyfúrásból csak egy volt sikeres, kettő félig tekinthető annak, míg a többi fúrás meddő lett. Viszont a földhőszivattyúk főleg az SMBben - világviszonylatban is jelentősen — fejlődnek

A hivatalos svájci energiastratégia (EN2050) szerint a jövőbeni áramtermelési technológiák közül a geotermia 2050-re évi 4,4 Terrawattóra mennyiségú áramot szolgáltatna. Ez 500 Megawatt teljesítményú erőmúveket igényelne, aminek fele hidrotermális, másik fele petrotermális (EGS) telepekből termelne. Hidrotermális telepek csak az SMB-ben létezhetnek, ezek valószínúsége azonban az eddigi adatok szerint csekély.

Elméletileg az EGS erőmûvek termelhetnek hőt, illetve áramot az SMB alatti alapkőzetből, azonban az EGS technológia múködőképessége még bizonyítandó. Ez irányú kutatás-fejlesztés több országban zajlik, de még számos nyitott kérdés van, melyek megválaszolásához jelentős forrásokra lenne szükség.

Tárgyszavak: potenciálbecslés, hasznositás-jellemzók, mély víztartók, földhöszivattyúk, EGS, energiastratégia

Abstract

Sedimentary basins usually have significant geothermal potential. Deep aquifers are key components. The factors, conditions, and processes that define and control the potential are on one hand the processes during basin formation like sedimentation, karstification, fracturing; for utilisation on the other the reservoir rock properties porosity, permeability; depth/temperature; the hydrogeology and nowadays the production sustainability ("specific characteristics") are decisive. These latter characteristics are demonstrated on selected examples: USA basins, Paris Basin, Molasse Basin. Of the latter, the French, German and Austrian parts are described first and then the Swiss Molasse Basin (SMB) in more detail.

The various efforts undertaken to assess and quantify the SMB potential are described, with example maps presented. The realisations of the SMB potential so far are really modest: of 10 deep drilling projects performed in various locations to date only one is successful and two are partial success. On the other hand, the geothermal heat pump systems develop mainly in the SMB, in a globally leading way.

The official Swiss energy strategy EN2050 includes electricity supply in the future; this assigns 4.4 TWh to geothermal sources in 2050. This would be delivered from geothermal power plants, foreseen are $250 \mathrm{MWe}$ installed capacity from hydrothermal reservoirs, and another $250 \mathrm{MWe}$ from petrothermal (EGS) sources. Only the SMB could host hydrothermal resources, but the current data do not show much potential. In principle, EGS plants could take heat (and convert it to electricity) from below the SMB. The EGS technology itself has great potential but it is still in the proof of concept stage. Intensive R\&D is ongoing in several countries, however very substantial funding will be needed to answer the many questions still open.

Keywords: parameters of potential, potential assessment, utilisation-relevant characteristics, deep aquifers, geothermal heat pumps, EGS, energy strategy 


\section{Introduction}

Sedimentary basins are classical hosts of oil and gas resources. Besides these, sedimentary basins can contain substantial geothermal resources as well, provided that various prerequisites are met. For a review see e.g. LIMBERGER et al. (2018). The direct utilisation of geothermal heat in the deeper subsurface is only possible when substantial amounts of heat carriers (in particular: formation fluids) are available, usually in deep aquifers. The usually stratiform aquifers must have high enough porosity and permeability, sufficient thickness as well as high enough temperatures. Then the fluids must be extracted and brought to the surface by means of production boreholes, in a technically feasible and economically viable manner. This kind of geothermal heat utilisation is called "hydrothermal". In the absence of "hydrothermal" the heat can be extracted by artificial circulation from the rocks, by Enhanced Geothermal Systems (EGS) - the "petrothermal" solution. The EGS technology is still in the proof of concept phase world-wide. For a comprehensive status report see BREEDE et al. (2013).

The aquifer characteristics (decisive for utilisation) are: the reservoir rock volume, porosity, permeability; depth/ temperature, the hydrogeology, and nowadays the production sustainability ("specific characteristics").

The following considerations first address geothermal potentials and utilisations in selected sedimentary basins in a general sense. Afterwards, the utilisation-specific characteristics are addressed, using the example of a particular basin. Finally, the Swiss Molasse Basin is treated in more detail.

\section{Definition of the geothermal potential}

First a few remarks on the term "potential". It is customary to use the term geothermal potential for "possibilities to use the heat content of the subsurface" - including all options of geothermal technologies. It is also common to distinguish between geothermal resources and reserves. Concerning the potential itself, various categories of it can be concretised; theoretical, technical, economical, sustainable, developable - decreasing successively in size. In this order the potentials are more and more realisable and more and more rewarding financially. For details see GoLDSTEIN et al. 2011 and RYBACH 2010, 2015. However, here the term potential will be used in its broadest sense.

Harvesting the geothermal potential can be realised with various technologies. In this process, the different depth domains of sedimentary basins are used with different technologies. The shallow domain (from the surface to about $300 \mathrm{~m}$ depth) is a ubiquitous heat source and store, even without geothermal fluids present. Here the geothermal heat pump systems operate, for space heating and/or cooling. For using the medium domain (from $300 \mathrm{~m}$ to about $3 \mathrm{~km}$ depth) a number of technologies are available, depending of the temperature of geothermal fluids present: bathing/wellness, agriculture, space heating, industrial uses. Fluid temperatures above about $100{ }^{\circ} \mathrm{C}$ enable even power generation or (in ideal cases) power/heat cogeneration. Usually, crystalline rocks form the basement of the basins; here (in principle) EGS systems could be established and operated. Not everywhere, but at certain places all three options could be operated in the same region.

\section{Basins and specific characteristics}

Sedimentary basins exist world-wide in large numbers. They host large amounts of geothermal heat and are broadly distributed geographically, including important population centers, see e.g. LIMBERGER et al. (2018). The sedimentary basins can be quite different in age/development history, lithology, architecture.

All basins have several specific characteristics in common, relevant for utilisation, see Introduction. These characteristics are addressed below, for individual basins. Their potential and current utilisations are also summarised.

\section{Deep sedimentary basins in the United States}

The USA has numerous, extended sedimentary basins. Several of them are up to $8 \mathrm{~km}$ deep, see e.g. TESTER et al. 2006).

As the specific characteristics, the criteria for high geothermal potential shall be addressed here. It can be expected that basins, which are characterised by porous and permeable reservoir rocks having sufficient temperature, thickness, porosity, and permeability have high geothermal potential. Besides, drilling depths should remain economic.

A special study, funded by the U.S. Department of Energy (DOE) was devoted to identify, screen and rank the 17 basins alone in western U.S. As expected, it was found that the main criteria for ranking were temperature, depth, porosity and permeability. For these, the following thresholds have been identified: $>125{ }^{\circ} \mathrm{C},<4 \mathrm{~km},>10 \%$, $>10 \mathrm{mD}$.

The results of the study, as reported by ANDERSON (2013), indicate that the following basins comply with these criteria: Denver, Forth Worth, Raton, Sacramento, Williston, and, especially Great Basin, Gulf Coast, and Imperial Valley basins. Some numerical values of the characteristics are given in Figure 1.

Here it should be mentioned that among the success factors/criteria the permeability of the thermal waterbearing rocks is usually the least well-known parameter. This is due to the fact that it is quite difficult to determine this property with measurements at the surface or even by well logging. Hopefully some innovative approaches like using seismic attributes like reflection intensity or relative acoustic impedance can yield reliable permeabilities at depth (for details see KHAIR 2013). 


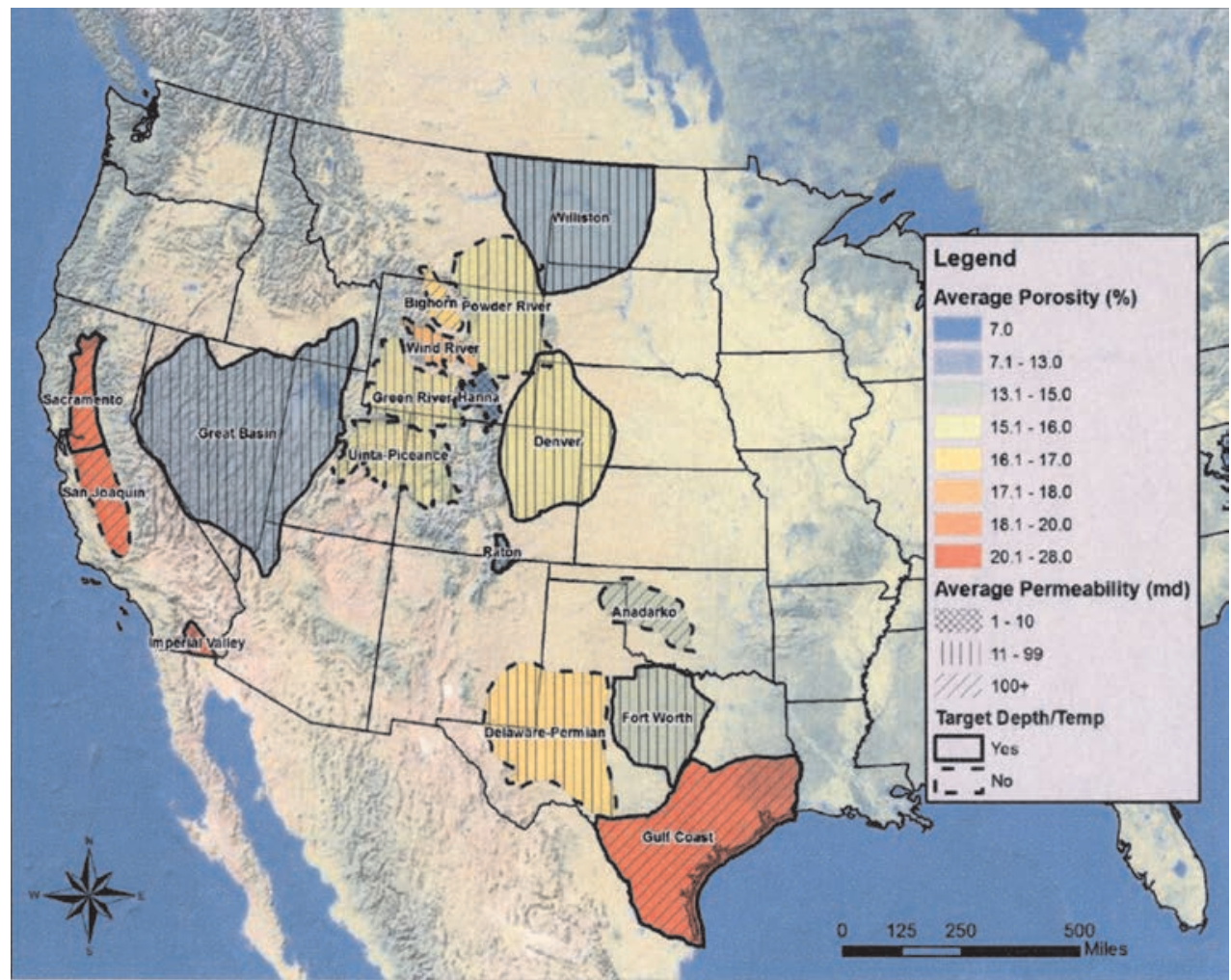

Figure 1. Variation of potential influence factors porosity, permeability, depth and temperature for sedimentary basins in the western U.S. Figure from ANDERSON (2013)

1. ábra. A geotermikus potenciált befolyásoló tényezök (porozitás, permeabilitás, mélység/hömérséklet) változása az Egyesült Államok nyugati üledékes medencéiben (ANDERSON (2013)

\section{European sedimentary basins}

The European continent also accommodates numerous deep sedimentary basins. In terms of their geologic style they can be categorised as orogenic belt foredeep, and marginal/back-arc basins. Several of them have been assessed, in view of their geothermal potential, by UNGEMACH \& ANTICS (2015). Here only a small number of them can be treated, mainly to highlight the specific, characteristic features.

\section{Paris Basin}

The Paris Basin is a typical intracratonic basin, see e.g. DERCOURT (2002). The main reservoir rock is the rather uniform Dogger aquifer (depth 1.6-1.9 km, production temperature $60-80{ }^{\circ} \mathrm{C}$ ), consisting of barrier reef facies carbonates. The basin has a long success story of utilising the aquifer for space/heating, especially by the doublet system with a pair of wells, one for production, the other for reinjection - some of the wells drilled deviated. A number of the doublets are operating since several decades. The doublet systems are especially numerous in the Paris Area (currently 37, Figure 2). They supply about 170,000 dwelling equivalents (BoISSAVy et al. 2013).

As the specific characteristic, the production sustainability shall be addressed here. The yield of production wells (flow rate, outflow temperature) is the key success factor of

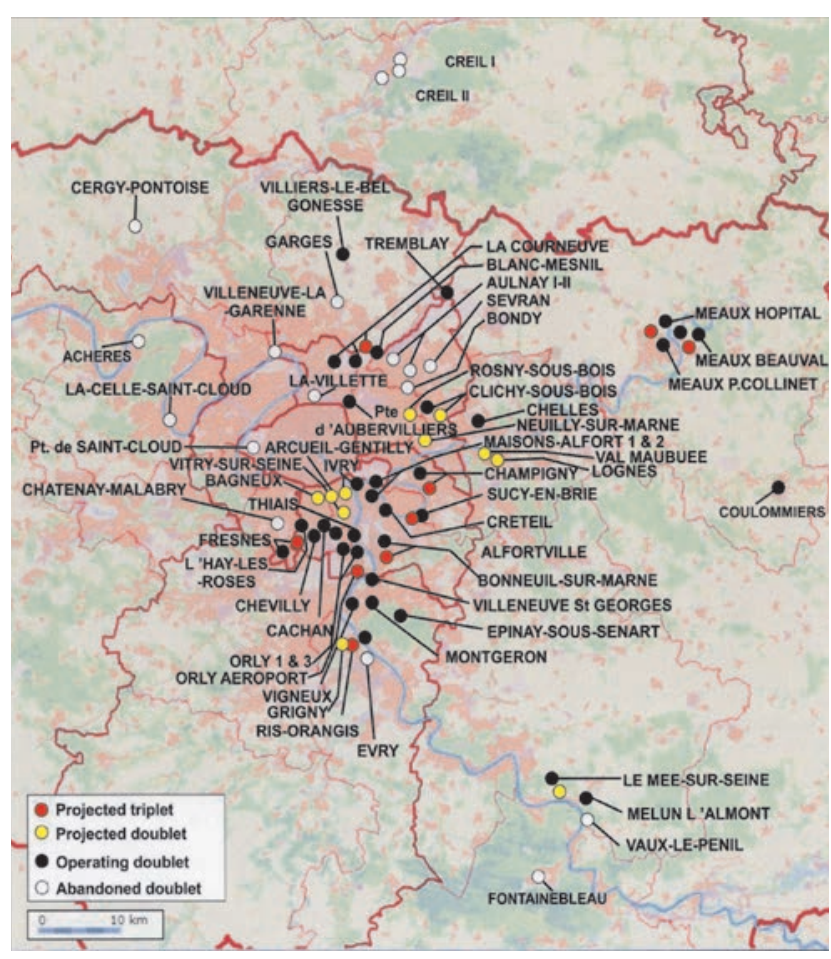

Figure 2. Doublet installations for district heating, in and around Paris, Paris Basin. Status in 2013. Figure from UnGEMACH \& ANTICs (2015)

2. ábra. Tervezett, meglévő és felszámolt termeló-visszasajtoló kútpárok a Párizsimedencében 2013-as adatok alapján (UNGEMACH \& ANTICS 2015) 


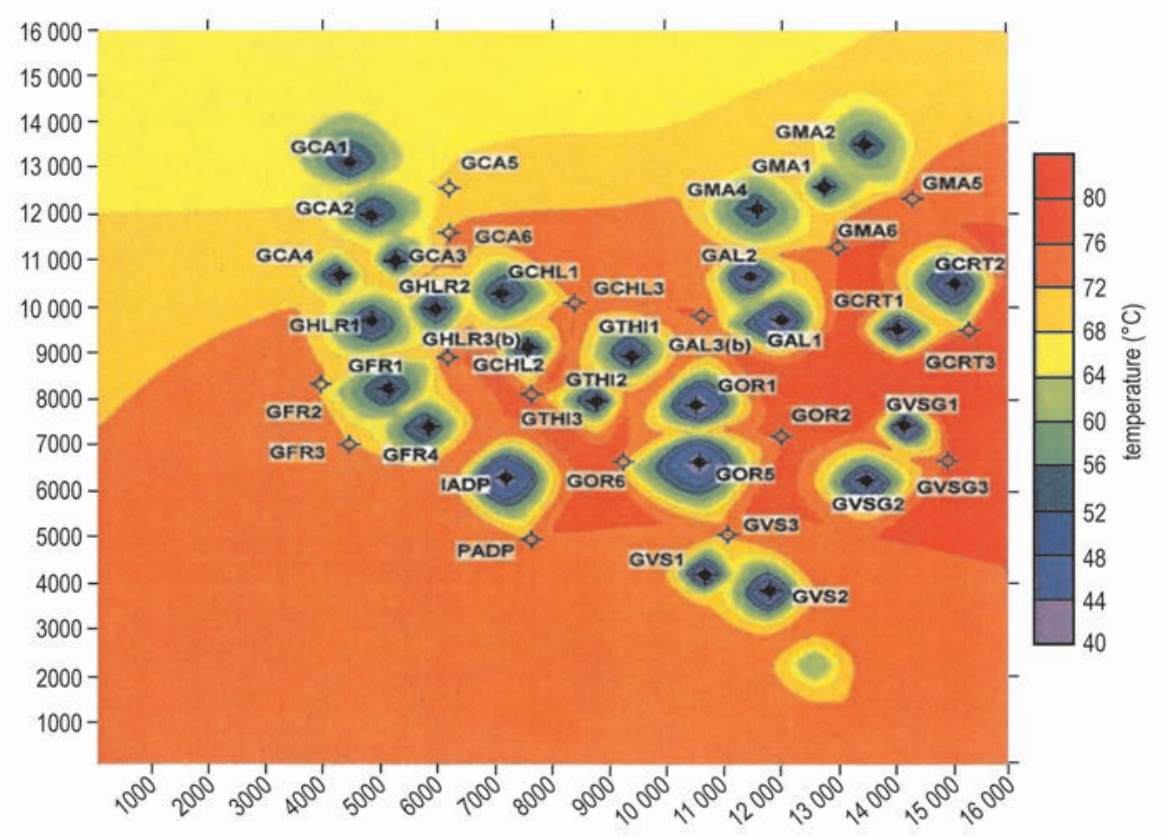

Figure 3. Multidoublet/triplet production modeling results for the time period 1984-2035, Paris Basin. Figure from UNGEMACH \& ANTICS (2015)

3. ábra. Termelö-visszasajtoló kutak 1984-2035 közötti termelése következtében kialakuló hömérséklet eloszlás numerikus modellje a Párizsi-medencében (UNGEMACH \& ANTICS 2015)

geothermal realisations; the doublet systems should function over decades possibly over hundred years. At the same time, environmental protection must be maintained.

Sustainability in geothermal practice "means practically the ability of the system to sustain production over long times" (RYBACH 2003). In the closed system of doublet operation sustaining the production flow-rate is not a problem since the reinjection stabilises the reservoir pressure. However, the cooling effect of the reinjected fluid will sooner or later reach the production well and thus continuously lower its outflow temperature. To counteract this, a doublet can be extended to a triplet: an original production well is changed to inject after a certain time and a new well is drilled sideward to produce. LE BRUN et al. (2011) suggest to do this after 25 years of doublet operation; then the triplet can be operated without temperature decline for 40 more years. Numerical calculations show (UNGEMACH et al. 2014) that the cooling effect in the reservoir can be significant, see Figure 3. The longevity of a doublet/ triplet system depends also on technical/mechanical factors like corrosion and/or scaling of the well, pump lifetime, etc.

Also the other French sedimentary basins (Aquitaine and Upper Rhine Graben) have substantial geothermal potential but currently the number of realisations in these basins is much lower than in the Paris Basin (VERNIER et al. 2015).

\section{Pannonian Basin}

The Pannonian Basin is a typical back-arc basin, see e.g. HoRvÁtH et al. (2015). Its deep aquifers are widely used especially in Hungary. The areal density of thermal boreholes is exceptionally high; practically every $10 \mathrm{~km}$ there is such a well (Figure 4). The thermal water is extracted mainly for bathing, wellness, etc. Besides, agricultural uses are also common; actually Hungary is a pioneer in geothermally heated greenhouses. It must be mentioned here that reinjection of used thermal waters is rather the exception than the rule. This might raise the question whether refill of the reservoirs by surface infiltration (or even from below?) can on the long run compensate for all the thermal water extracted by the boreholes.

Hungarian colleagues, present and passed away, are or have been much more knowledgeable about the geothermal potential, the geohydraulics, the utilisation schemes, etc. than the author of this paper. Here I would like to mention especially my colleagues and friends Mihály ERDÉLYI $(\dagger)$, Ferenc Horváth ( $\dagger$ ), Anita JobBIK, Árpád Lorberer $(\dagger)$, Judit MÁdL-SzŐNYI, Annamária NÁdor, Lajos STEGENA (†), János SZANYI, Péter Szúcs, Anikó TóTH, and József TóTH.

They all contributed to the discovery, characterisation and utilisation of the rich geothermal resources of the Pannonian Basin. From all of them, only two can be mentioned here.

The origin and development of geothermal resources is closely related to the geologic conditions and processes during basin formation. For the Pannonian Basin, the publication by HORVÁTH et al. (2015) describing these is in these regards a milestone. Decades ago, Ferenc HoRvÁtH was already active in geothermal development in the Pannonian Basin, see e.g. OTTLIK et al. (1982).

The specific characteristic to highlight here is hydrogeology, in particular the subsurface hydraulics of fluid movement. At the earth's surface, water flows only downwards. Not so in the subsurface: driven by the relief of the groundwater table, water can move even upward gravity driven, cross-formational flow, introduced already in the early 1960s by J. То́тн). The book by То́тн (2009) describes in 




Figure 4. Locations of geothermal drillings in the Pannonian Basin, utilising thermal waters from Pannonian reservoir rocks. A) thermal bath and wellness facilities, B) Space heating included. Figure from HoRváTH et al. (2015)

4. ábra. Üzemelö termálkutak helye a Pannon-medencében, A) balneológiai hasznositás, B) geotermikus távhö szolgáltatás is (HoRVÁTH et al. 2015)

detail his fundamental concept (that practically modernised hydrogeology) and many applications of it to sedimentary basins, also to the Pannonian Basin (TóTH \& ALMÁsI 2001).

\section{Molasse Basin}

The Molasse Basin is a typical orogenic belt foredeep basin. It extends in the foreland of the Alps from France in the west over Switzerland, Germany, Austria and the Czech Republic to the east (Figure 5). A general overview can be found in BACHMANN et al. (1986). The basin is clearly asymmetric; the greatest thickness is usually at the Alpine front whereas it gets gradually thinner away from the leading edge of the folded belt (Figure 6). In principle, the basin accommodates Mesozoic to Quaternary sediments; locally some members are missing.

As the specific characteristic, here the variety of reservoir rocks hosting prospective aquifers, should be mentioned. In principle, porous, karstic, or fractured rocks have enough porosity and permeability to become productive aquifers. Generally speaking, porous sandstones, karstic carbonates or those developed in reef facies have been found and utilised in the Molasse Basin. Seismic reflection can locate fractures as well as reef-facies limestones; for details see in HARTMANN et al. (2015), or SHIPILIN et al. (2019). Rather recently, fractured reservoirs, with fracture permeability, received attention. For the Molasse Basin, MoEcK et al.
(2015) describe multiple normal faults to have a certain potential, whereas SILER et al. (2015) demonstrate the potential of fracture permeability in general, also in volcanic areas.

Some information about potential in the westernmost part of the Molasse Basin located in France (Geneva-Savoy area, based mainly on deep temperature distributions) is

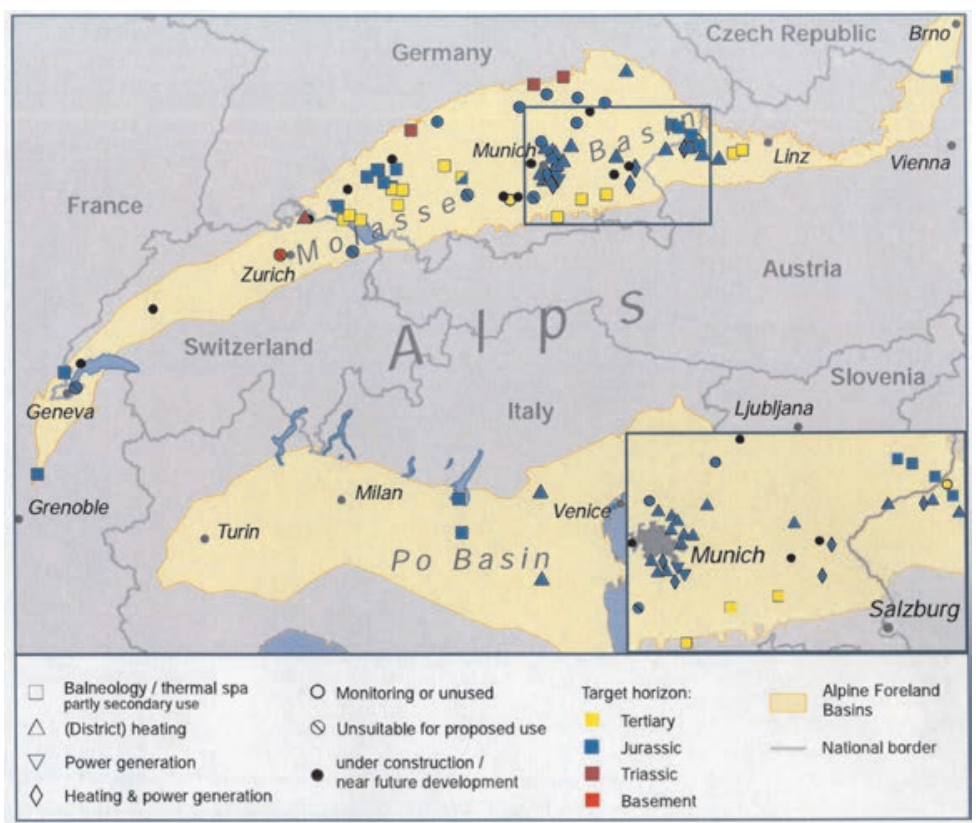

Figure 5. Geothermal installations in sedimentary basins north and south of the Alps. Figure from GeoMol (2019)

5. ábra. Geotermikus energia hasznositási típusai az Alpok északi és déli üledékes medencéiben a rezervoárok kora szerint (GeoMol 2019) 


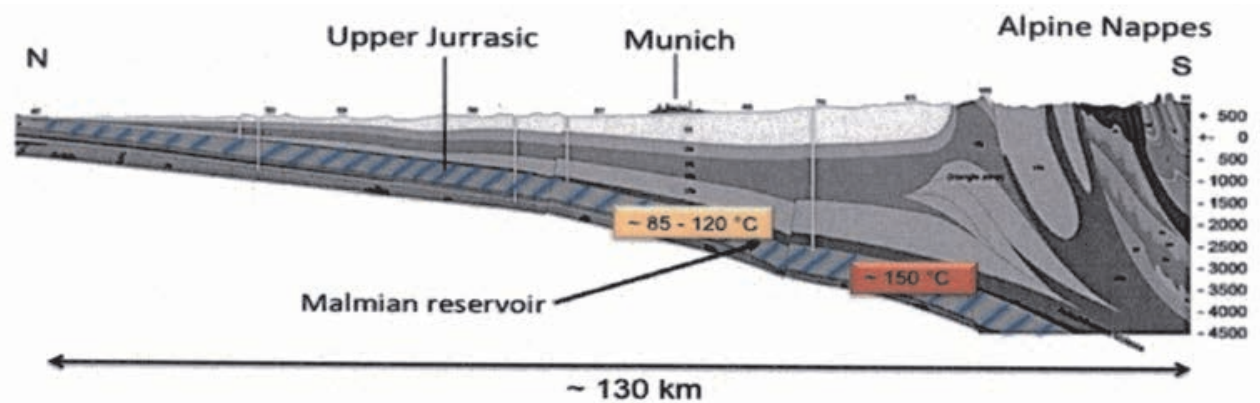

Figure 6. Geologic cross section across the German part ot the Molasse Basin, through the location Munich. The asymmetric architecture of the basin is evident. Figure from UNGEMACH \& ANTICS (2015)

6. ábra. Geológiai szelvény a Molasse-medence aszimmetrikus német részén Münchenen keresztül (UNGEMACH \& ANTICS 2015)

given in GeoMol (2018. Before turning to the Swiss Molasse Basin, the German and Austrian parts are addressed.

\section{German Molasse Basin}

The Molasse Basin in southern Germany extends over more than $300 \mathrm{~km}$ from Switzerland in the south-west to Austria in the east. The basin is made up mainly by Cenozoic, Upper Jurassic (Malm) and Triassic sediments. Eight aquifers of these sediment layers are of interest for direct use of geothermal energy: Burdigalian, Aquitanian and Chattian sandstones, Baustein and Ampfinger beds, Gault and Cenomanian sandstones, Malm and Triassic Upper Muschelkalk.
Of these units, the Malm (limestone aquifer of the Upper Jurassic) is up to $600 \mathrm{~m}$ thick and is generally productive. The Malm aquifer dips from north to south to increasing depths and temperatures (details for the above see in WEBER et al. 2015).

The varying reservoir rock lithology, facies, and karst are the specific characteristics here.

Typically for carbonates, the Malm is a complex and heterogeneous geothermal reservoir with considerably varying reservoir properties on exploration relevant scales. DIRNER \& STEINER (2015) showed that reservoir potential (yield) is highly dependent on carbonate facies and diagenetic overprint (e.g. dolomitisation and karstification).

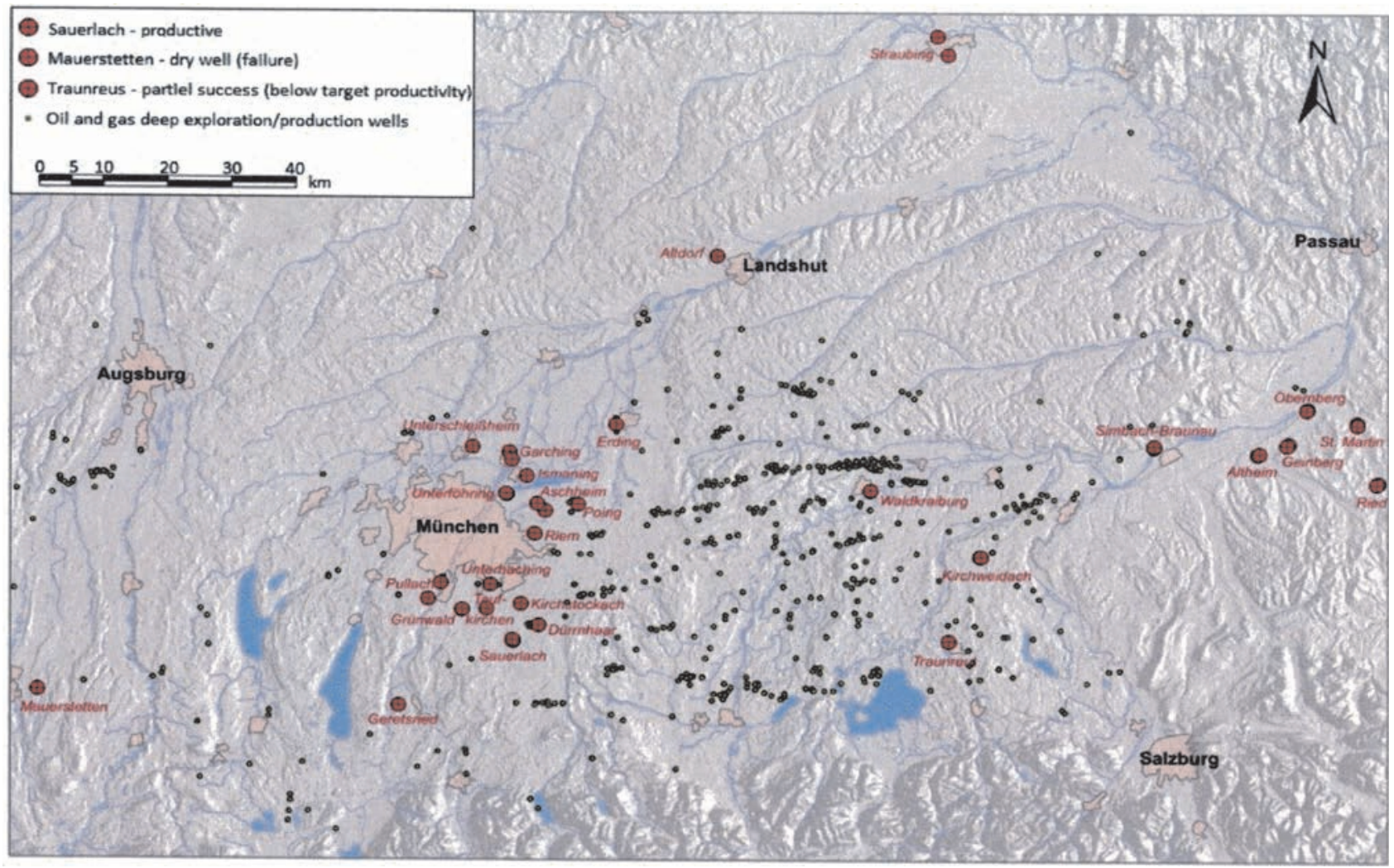

Figure 7. Geothermal installations in the Molasse Basin. Mainly around Munich. Figure from UNGEMACH \& ANTICS (2015)

7. ábra. Geotermikus energia hasznositási helyei a Molasse-medencében München térségében a fúrások sikeressége szerint, a szénhidrogén kutak feltüntetésével (UNGEMACH \& ANTICS 2015) 
Reservoir characterisation on the basis of borehole data (e.g. cuttings, image logs, etc.) and the correlation to seismic data can improve the predictability of potential.

In the north-eastern and central parts of the basin the Malm is present in the Swabian and Franconian Alb facies (frequently with massive reefs), in the south-western part of the basin in Helvetic facies. The Helvetic facies is characterised by organicrich, bedded limestones with low permeabilities. Karstification is not observed (HOMUTH et al. 2015).

The utilisation activities (mainly district heating) concentrate currently in the Munich area (Figure 7).

\section{AUSTRIAn Molasse BASIN}

The Austrian part of the Molasse basin is located in Upper Austria, bordering to Germany, see Figure 5 and 8 . It is so far the most developed geothermal area in Austria. The main aquifer is in Upper Jurassic (Malmian) dolomites and limestones (GOLDBRUNNER 2015). Temperatures up to to $300 \mathrm{~m}$ depth). The subsurface in this depth domain is a heat source on one hand and a heat store on the other. This fact is the basis of the Geothermal Heat Pump (GHP) technology. For a general description of the technology see Lund et al. (2003).

In moderate climate, GHP systems can be used for space heating and/or cooling. In principle, they can be installed everywhere, except for groundwater protection areas. Thus they could be used in most sedimentary basins!

The GHPs currently provide about $50 \%$ of total geothermal heat world-wide! (IEA 2011). Besides, this is the fastest growing branch of geothermics, and also one of the most growing branches in renewable energy technologies. The world-wide installed capacity increased with an annual growth rate of $20 \%$ exponentially, from 2.0 GWth in 1995 to about $80 \mathrm{GW}$ th in 2015. The technology is fully mature; it is described e.g. in LUND et al. (2003) or RYBACH (2012a).

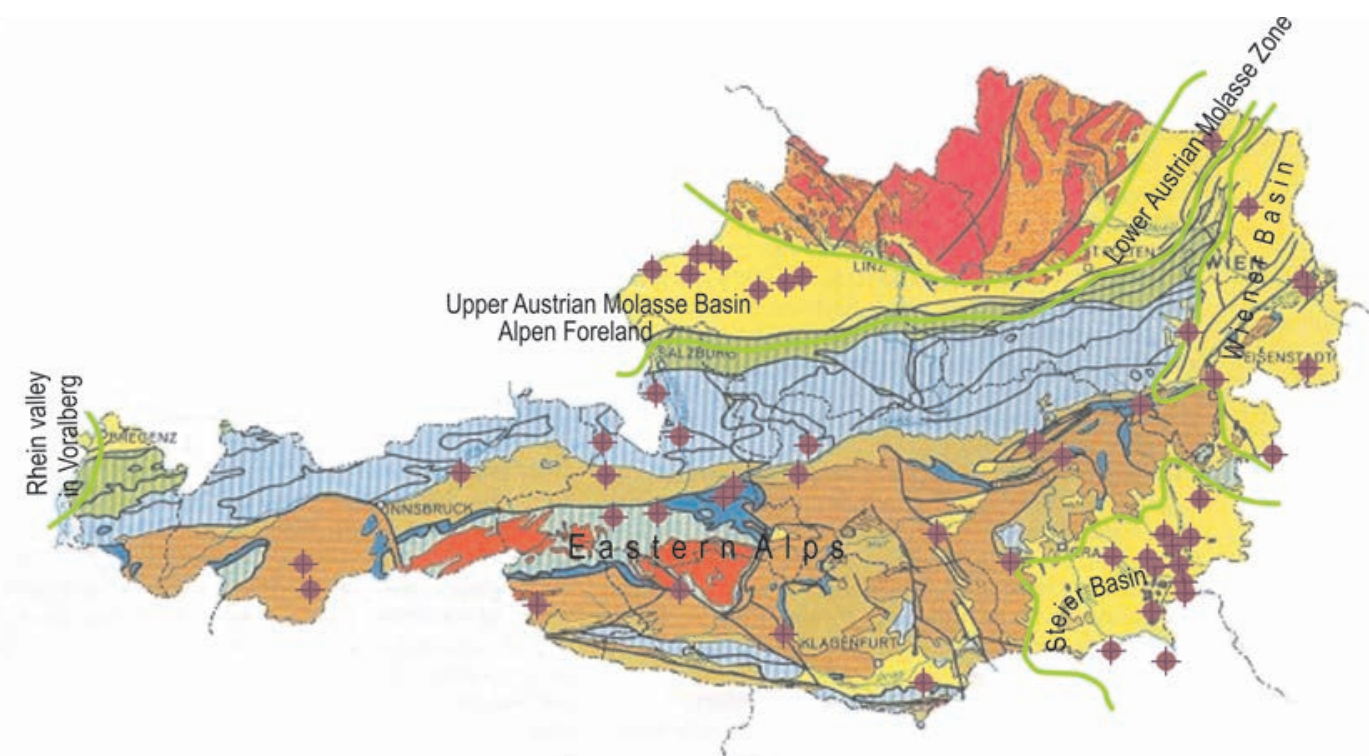

Figure 8. The Molasse Basin in northern Austria is a narrow band. Operating installations concentrate at the western end. Figure from GOLDBRUNNER (2015)

8. ábra. Geotermikus energia hasznositási helyei a Molasse-medence osztrák részének keskeny nyugati végében (GOLDBRUNNER 2015)

$130{ }^{\circ} \mathrm{C}$ can be achieved. Currently 7 geothermal district heating projects are in operation with 13 boreholes, besides 3 spa facilities (Therme Geinberg; Institut Zelleis in Gallspach; Eurotherme Resort in Bad Schallerbach).

Before moving to the Swiss Molasse Basin, the most advanced geothermal technology should be highlighted here, especially in view of the Swiss success story in this field, which has its broadest base in the Swiss Molasse Basin itself.

\section{A key player in geothermal energy}

In any location/area/region one geothermal resource/ potential should not be forgotten: the shallow (down about
It will be shown below that Switzerland is a world leader in this technology, mostly due to the GHP systems installed in the Swiss Molasse Basin.

\section{Swiss Molasse Basin (SMB)}

The SMB extends from the Lake of Geneva in the west to the Lake of Constancein the east. For the boundaries in north and south see Figure 9, for a general overview PFIFFNER (1986). The first study about the geothermal potential with numerical values — was performed in the early 1990s (RYBACH 1992). It covers shallow, intermediate / hydrothermal and deep resources, with corresponding technologies (GHP, direct uses, EGS). 


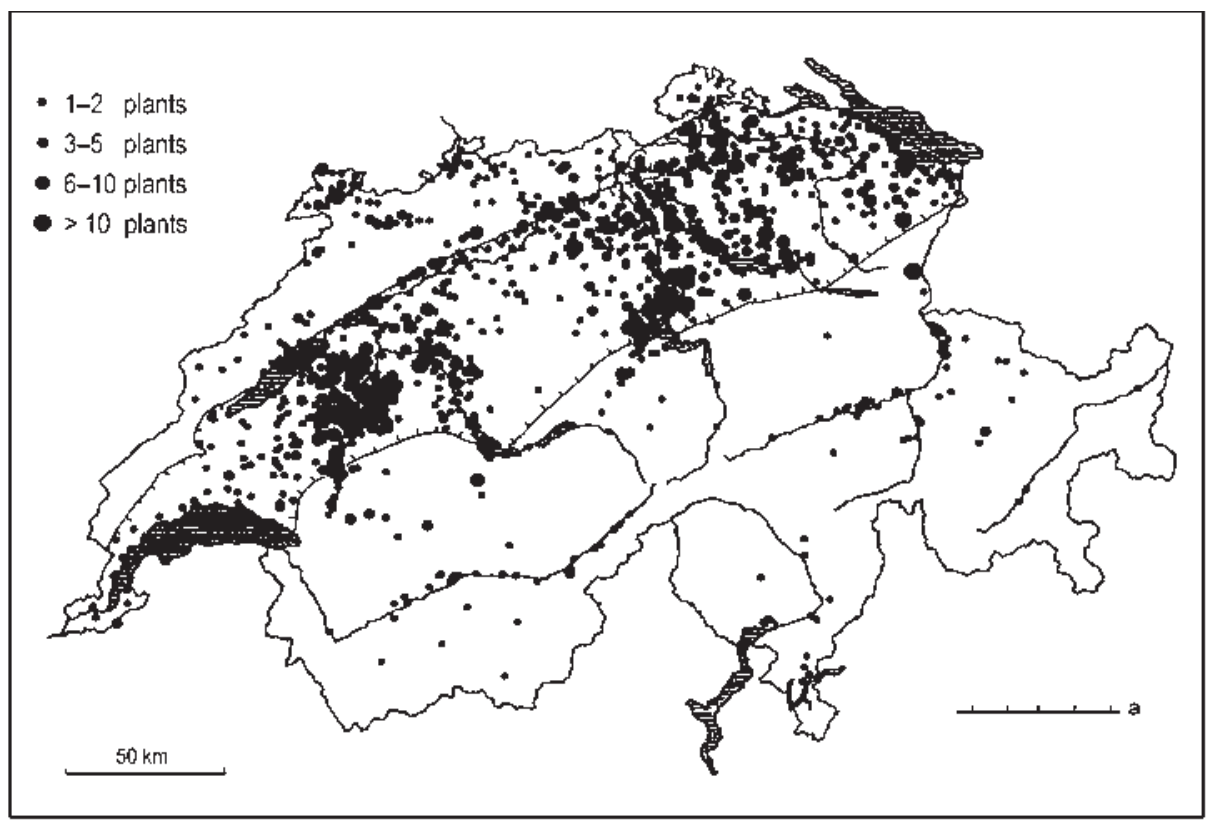

Figure 9. Installation sites of geothermal heat pump system with borehole heat exchangers in the SMB (line "a": basin boundary). From RYBACH (1992)

9. ábra. Geotermikus hőszondák helyei a Svájci Molasse-medencében (SMB) a szondaszám függvényében (az „„” vonal jelzi a medencehatárt) (RYBACH 1992)

\section{GHP systems}

GHP systems operate in Switzerland mainly with borehole heat exchangers (BHE). They can be installed for a great variety of buildings, with just $1-2$ BHEs in single family houses to great complexes like the buildings at the Hönggerberg Campus of ETH Zurich over 400 BHEs. In 2017, Swiss GHP systems delivered 3.6 GWh heat, with an installed capacity of $2.0 \mathrm{GWth}$ (LiNK 2018).

The density of GHP installations is highest in the area of the Swiss Molasse Basin; this is due to the similarly high population density there. Figure 9 shows the situation in 1991; since then the number of GHP installations increased so much that they could not be plotted anymore. Switzerland extracts with GHPs the most heat from the ground per unit surface area in Europa: on average $0.264 \mathrm{TJ} /$ year per $\mathrm{km}^{2}$ (RYBACH \& SANNER 2017). This number is most probably the highest world-wide. The growth of this technology and the significant installation cost reduction over the last decades is a real Swiss success story; details see in RYBACH (2012b).

The RYBACH (1992) GHP potential assessment for the SMB came up with $5000 \mathrm{TJ} /$ year heat (Technical Available Potential, TAP). For comparison, the Swiss official statistics 2017 quoted in RYBACH \& SANNER (2017) reports already 11 $\mathrm{PJ} / \mathrm{yr}$ produced heat for the whole country. GHP systems are still growing in Switzerland; hence the 1992 assessment (for the SMB alone) was quite on the modest side.

\section{Hydrothermal systems}

There are no thermal springs in the SMB, which could be a category of geothermal direct use, see e.g. RYBACH (1992).
This fact indicates that in the basin the vertical permeability (even in steep fracture systems) is rather low. Therefore, only deep, stratified aquifers remain the medium of geothermal potential.

The RYBACH (1992) potential assessment remains vague about deep aquifers, mainly due to the lack of drilling results , but mentions the exploration risk (not finding the expected well productivity). The correspondingly uncertain numerical values of the technically available potential (TAP) for the Miocene upper marine Molasse and the Triassic Upper

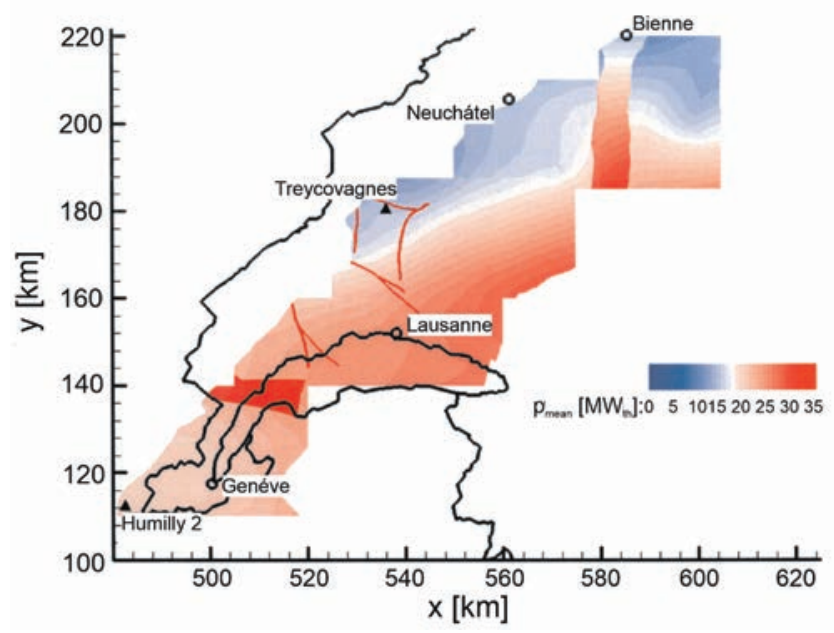

Figure 10. Estimated geothermal power of the Upper Muschelkalk aquifer in the western part of SMB. Black triangels: deep boreholes. Figure from BAUJARD et al. (2007)

10. ábra. Becsült geotermikus teljesítmény (MWth) a felsö-Muschelkalk vízadóban a Svájci Molasse-medence (SMB) nyugati részén. Fekete háromszögek a mélyfúrásokat jelölik (BAUJARD et al. 2007) 




Figure 11. Estimated geothermal power of the Upper Muschelkalk in the north-eastern part of SMB. The NW-SE increase is due to the increasing depth of the aquifer in this direction. Names indicate sites of deep boreholes. Scale in MWth. Figure from SIGNORELLI \& KoHL (2007)

11. ábra. Becsült geotermikus teljesítmény (MWth) a felsö-Muschelkalk vízadóban a Svájci Molasse-medence (SMB) északkeleti részén a mélyfúrások nevének feltüntetésével (SIGNORELLI \& KOHL 2007)

Muschelkalk were estimated to be only 2,500 and 3,600 $\mathrm{TJ} /$ year.

More recently, several geothermal resource assessments were published, covering nearly the entire SMB: BAUJARD et al. (2007), SignORELli \& KoHL (2007). KoHL et al. (2010). These assessments forecast the possible geothermal productivity of aquifers (by doublet systems) over a 30-year life span of a utilisation scenario. On the basis of measured data and numerical interpretations, the temperature field within the basin, and the hydraulic transmissivity of the most important hydrogeological structures have been regionally assessed. Using these two key parameters the productivities were predicted for the SMB. The final results are presented in numerous maps; here only a small section is displayed (Figures 10 and 11). BAUJARD et al. (2007) report for the Upper Muschelkalk aquifer in the Western SMB a a TAP resource of 2,700 PJ, whereas SIGNORELLI \& KOHL (2007) 2,900 PJ for the northern part; both for a production period of 30 years.

The Malm layers appear in the SMB also in Helvetic facies (properties see under German Molasse Basin). Unlike the intensive karstification in the German Molasse, the Malm karst in the SMB is low on one hand, on the other the karst cavities are usually sealed by fine-grained Eocene clays (Bohnerz Formation). This certainly limit their potential The Upper Muschelkalk carbonates are therefore more prospective.

The assessment in both parts of the basin shows that the overall SMB potential is not uniformly distributed over the basin (Figure 12).

Very recently, the publication by CHELLE-Michou et al. (2017) describes the geothermal state of the deep Western Alpine Molasse Basin, stretching from the French basin end at Aix-lesBains/Lac d'Annecy to Yverdon/Lac de Neuchâtel in Switzerland. It presents, besides constituting a

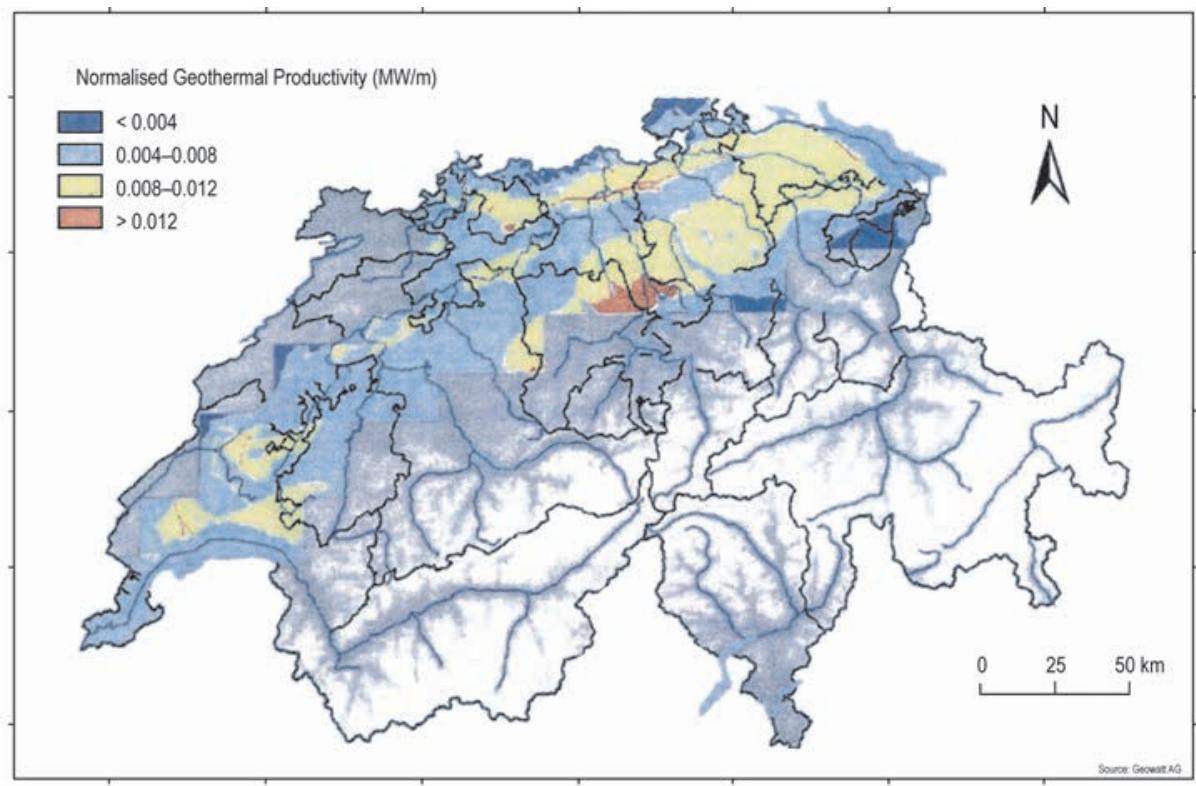

Figure 12. Depth-corrected representation of a normalised geothermal productivity including the following aquifer: topmost fractured crystalline, Upper Muschelkalk and Upper Marine Molasse in Northern and Western Switzerland. The estimated mean geothermal productivity for each aquifer has been divided by the local depth. Figure from KoHL et al. (2010). For the SMB boundaries see Figure 9

12. ábra. Mélységgel normált geotermikus produktivitás (MW/m) Észak-és Nyugat-Svájcban (SMB) a következő vízadók figyelembevételével: legfelsö töredezett kristályos közet, felsö-Muschelkalk és felsö tengeri-Molasse (KoHL et al. 2010). Az SMB határait lásd 9. ábra 
borehole data-driven 3D geostatistical temperature model of the basin, considerations about the geothermal potential. In particular, it states that "the great geothermal potential of the basin for low-enthalpy resources makes little doubt". It is further claimed that the potential is associated with faulted and karstic reservoirs. Here it should be mentioned that the faults might be restricted in amount and extension - besides having some risks of seismicity, which could be induced by geothermal operations, like reinjection. The extent and intensity of karstification is also mainly unknown.

A certain potential could be related to Permo-Carboniferous troughs below the basin, especially due to potentially uprising warm waters along their boundary fault-zones. Such have been clearly detected in Canton Aargau, as demonstrated in GRIESSER \& RYBACH (1989). Whether the top of the crystalline basement underlying the basin is more permeable than further below (and if so, to what depth) is still unclear. Nevertheless this zone could also have geothermal potential.

\section{Outlook: Future expectations in and challenges for $S M B$}

The annual electricity demand in Switzerland in 2018 amounted to 57.6 TWh, see SFFO (2019), the currently operating Swiss nuclear power plants produced 24.4 TWh. As the result of public voting, the power plants should be decommissioned; the first in 2020, the last about in 2030. The official Swiss Energy Strategy of the Government ES2050 (SFOE, 2015) foresees to fill the resulting gap until 2050 (besides imports) by electricity saving on one hand, and by new renewable energy power installations on the other. The Swiss geothermal electricity supply should increase from zero today to $4.4 \mathrm{TWh}$ in 2050 . This is about $7 \%$ of the current demand. The 4.4 TWh in 2050 would require about $550 \mathrm{MWe}$ installed power plant capacity (details see in LinK et al. 2019).

This is a very, very ambitious goal! It is foreseen that about half of the capacity should come from hydrothermal, the other from EGS resources - as indicated in Figure 13. Based on present knowledge it is highly questionable if efficient hydrothermal resources are present in Switzerland that could provide a power capacity of $250 \mathrm{MWe}$. From resources in the SMB most probably not. Deep aquifers with wide lateral extension and high geothermal potential are rare, contrary to the German or Austrian parts of the Basin. Up to now, 10 deep boreholes have been drilled at several locations, all over the SMB: in Kreuzlingen (1988), Bulle (1992), Bassersdorf (1993), Weissbad (1993), Geneva (1993), Zürich Triemli (2010), Schlattingen (2011, 2013), St. Gallen (2013) and Satigny (2018). Of these, only one drilling was successful and seven were a failure. From the rest of Switzerland (Jura and Alps), little is known in terms of geothermal potential; current knowledge indicates low probability of success to find hydrothermal resources.

The other half of the $4.4 \mathrm{TWh}$ should come from Enhanced Geothermal Systems (EGS), producing with 250 MWe. Theoretically this is possible since hot deep rocks are present everywhere and could deliver enough heat (with temperatures above $100{ }^{\circ} \mathrm{C}$ ). But the question is: how?

The EGS technology itself has great potential but it is still in the proof of concept stage. One of the key problems is the creation of an efficient, deep heat exchanger. This should consist of an extended, well interconnected, suf-

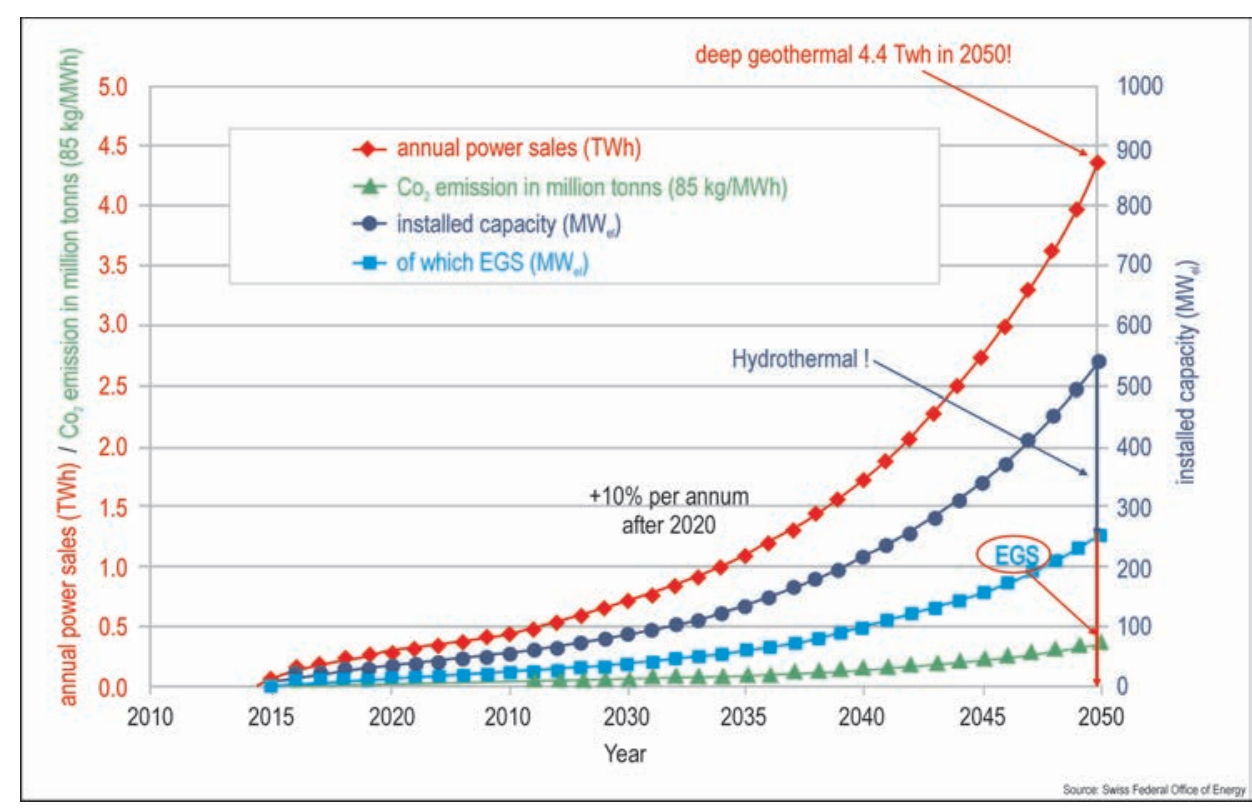

Figure 13. The official "Swiss Energy Strategy 2050" of the government sets ambitious goals: it calls for 4.4 TWh electricity from geothermal sources. This could hardly come from the SMB. For details see text

13. ábra. A hivatalos „Svájci Energiastratégia 2050” ambiciózus célja 4,4 TWh elektromos energia elöállitása geotermiából. Ez aligha tud megvalósulni a Svájci Molasse-medencéböl (SMB) 
ficiently permeable fracture network. It is foreseen to realize this network by hydraulic stimulation, without induced seismicity. Establishing such heat exchangers need to be possible regardless of the local subsurface conditions, should the EGS technology be ubiquitously applicable as advocated for by TESTER et al. (2006). Intensive R\&D is ongoing now in several countries to find solutions to these problems (see BREEDE et al. 2013); however very substantial funding will be needed to answer the many questions still open.

Should the EGS technology be ready to implement, then crystalline rocks below the SMB would be suitable candidates. Details see in RYBACH et al. (1978).

\section{Some final remarks}

Moderate to great geothermal potentials can exist in many sedimentary basins. Currently there is growing interest about this potential As an example: the University of Alberta is organising a research conference on the geothermal potential of sedimentary basins, 14-18 October 2019 in Edmonton, Canada. Topics include geoscience, engineering, policy, regulation, and social license issues.

A novel, promising future development would be the use of oil/gas wells for coproduction of hot water or utilizing unused/abandoned wells for geothermal purposes. Especially in Alberta, Canada there are many thousand boreholes; quite a number of them are envisaged for this option, see e.g. MAJOROWICZ et al. (2013). It is interesting to note, that already the third "Hydrocarbon-Geothermal Technology Crossover Workshop" took place in Geneva, Switzerland on 9-10 April 2019, organised by AAPG (American Association of Petroleum Geologists) and IGA (International Geothermal Association). The theme was "Making Geothermal Energy Profitable: from Subsurface Uncertainties to Viable Business Models“. Joining forces of geothermal developers with the oil/gas industry (the dominant global players in sedimentary basins) would be highly beneficial; cooperating oil/gas and geothermal experts and developers would be a dream team!

\section{Conclusions}

In general, sedimentary basins have significant geothermal potential. Deep aquifers are key components. The factors, conditions, and processes that define and control the potential are: processes during basin formation like sedimentation, karstification, fracturing; rock porosity, permeability / fluid content; depth/temperature; hydrogeology; production sustainability. These factors are demonstrated using the example of the following basins: U.S. basins, Paris Basin, Pannonian Basin, Western and Eastern parts of the Molasse Basin, and specially and in more detail on the Swiss Molasse Basin (SMB).

The absence of thermal springs in the SMB (with one exception) indicates that vertical permeability in the basin (e.g. in steep fracture systems) is rather low.

A number of efforts were undertaken to assess and quantify the SMB potential. They present various numbers on numerous maps, especially about deep aquifers. The realisation of their potential in the SMB is so far really modest: from 10 deep drilling projects started in various locations to date only one is successful, two are partial success.

Based on the current data base and knowledge about deep aquifers in the SMB it will hardly be possible to fulfill the requirements of the Swiss Energy Strategy EN2050, which requires geothermal power plants with an installed capacity of 250 MWe capacity based on hydrothermal resources.

The situation is much better in utilising the shallow subsurface: the extensive deployment of geothermal heat pumps - especially in the SMB - is a Swiss success story, which made the country a world leader in the use of this technology.

\section{Acknowledgment}

Sincere thanks are due to three reviewers, for their constructive remarks and requests.

\section{References — Irodalom}

Anderson, T. 2013: Geothermal Potential of Deep Sedimentary Basins in the United States. - Geothermal Resources Council Transactions 37, 223-229. https://doi.org/10.1190/urtec2013-202

Bachmann, G. H., Müller, M. \& Weggen, K. 1986: Evolution of the Molasse Basin (Germany, Switzerland). — Tectonophysics 137, 77-92.

Baujard, C., Signorelli, S. \& Kohl, T. 2007: Atlas de ressources géothermique de la Suisse occidentale — domaine sud-ouest du Plateau Suisse. —Matériaux pour la Géologie Suisse, Géophysique 40, 56 p.

Boissavy, C., Vernier, R. \& Laplaige, P. 2013: Geothermal Energy Use, Country Update for France. - Proceedings, Geothermal Energy Congress 2013, 12 p.

Breede, K., Dzebiashvili, K., Liu, X. \& Falcone, G. 2013: A systematic review of enhanced (or engineered) geothermal systems: past, present and future. - Geothermal Energy 1, 1-27.

Chelle-Michou, C., Do Couto, D., Moscariello, A., Philippe Renard, Ph. \& Rusillon, E. 2017: Geothermal state of the deep Western Alpine Molasse Basin, France-Switzerland. — Geothermics 67, 48-65. https://doi.org/10.1016/j.geothermics.2017.01.004 
DERCOURT, J. 2002: Géologie et géodynamique de la France. - - 3e ed., Dunod, 336 p.

Dirner, S. \& SteIner, U. 2015: Assessing Reservoir Uncertainty with Stochastic Facies Modeling of a Hydrothermal Medium Enthalpy Reservoir (Upper Jurassic Carbonates of the Southern German Molasse Basin). — Proceedings, World Geothermal Congress 2015, $11 \mathrm{p}$.

GeoMol Team 2015: GeoMol - Assessing subsurface potentials of the Alpine Foreland Basins for sustainable planning and use of natural resources. - Project Report, 188 p. (Augsburg, LfU)

Goldbrunner, J. 2015: Austria Country Update. - Proceedings, World Geothermal Congress 2015, 13 p. https://doi.org/10.1016/ j.geothermics.2015.11.003

Goldstein, B. A., Hiriart, G. L., Tester, J. W., Bertani, R., Bromley, C., Gutierrez-Negrin, L., Huenges, E., Ragnarsson, A., Mongillo, M., Muraoka, H. \& Zui, V. I. 2011: Great expectations for geothermal energy to 2100. — Proceedings, Thirty-Sixth Workshop on Geothermal Reservoir Engineering Stanford University, Stanford, California, 31 January 2 -February 2011.

GRIESSER, J. \& RYBACH, L. 1989: Numerical thermohydraulic modeling of deep groundwater circulation in crystalline basement: An example of calibration. - In: Beck., A. E., GArven, G. \& StegenA, L. (eds): Hydrogeological Regimes and Their Subsurface Thermal Effects. American Geophysical Union, Geophysical Monograph 47/2, 65-74. https://doi.org/10.1029/GM047p0065

Hartmann, H., Beilecke, T., Buness, H., Musmann, R. \& Schulz, R. 2015: Seimische Exploration für Tiefe Geothermie. Geologisches Jahrbuch Reihe B 104, 271 p.

Hoмuth, S., GötZ, A. \& SASS, I. 2015: Physical Properties of the Geothermal Carbonate Reservoirs of the Molasse Basin, Germany Outcrop Analogue vs. Reservoir Data. _Proceedings, World Geothermal Congress 2015, 11 p.

Horváth, F., Musitz, B., Balázs, A., Végh, A., Uhrin, A., NÁdor, A., Koroknai, B., Pap, N., Tóth, T. \& Wórum, G. 2015: Evolution of the Pannonian basin and its geothermal resources. — Geothermics 54, 328-352. https://doi.org/10.1016/ j.geothermics.2014.07.009

IEA 2011: Technology Road Map - Heat and Power. 45 p. (Paris, International Energy Agency)

KhaIR, A. H. 2013: Coupling Petrography and Seismic Attributes for Locating Permeable Zones in the Cooper Basin/South Australia, Possible Workflow for Geothermal Projects. — Proceedings, Australian Geothermal Energy Conference 2013, 5 p.

Kohl, T., Schill, E. \& Baujard, C. 2010: Geothermische Ressourcenbewerung in Hinsicht auf mögliche Nutzungskonflikte im Schweizer Molassebecken. — Zeitschrift für Geologische Wissenschaften, Berlin 38/1, 27-39.

Le Brun, M., Hamm, V., Lopez, S., Ungemach, P., Antics, M., Ausseur, Jy., Cordier, E., Giuglaris, E., Goblet, P. \& Lalos, P. 2011: Hydraulic and thermal impact modelling at the scale of the geothermal heating doublet in the Paris Basin, France. - Proceedings, Thirty-Sixth Workshop on Geothermal Reservoir Engineering Stanford University, Stanford, California, January 31 - February 2, 2011. $14 \mathrm{p}$.

Limberger, J., Boxern, T., Plujmaekers, M., Bruhn, D., Manzella, A., Calcagno, P., Beekman, F., Cloeting, S. \& Van Wees, J.-D. 2018: Geothermal energy in deep aquifers: A global assessment of the resource base for direct heat utilisation. - Renewable and Sustainable Energy Reviews 82, 961-975.

LinK, K. 2018: Statistik der geothermischen Nutzung in der Schweiz — Ausgabe 2017. — Energie Schweiz, Bern, 59 p.

Link, K., SiddiqI, G. \& LupI, N. 2019: Geothermal Energy Use, Update for Switzerland. Proceedings, European Geothermal Congress 2019, p. 13.

Lund, J., SAnner, B., Rybach, L., Curtis, R. \& Hellström, G. 2003: Ground source heat pumps - A world review. - Renewable Energy World, July-August 2003, 218-227.

Majorowitz, J., Hofmann, H. \& Babadagli, T. 2013: Deep Geothermal Heat Storage Under Oilsands — Can We Use it to Help Oilsands Industry? - Geothermal Resources Council Transactions 17, 6 p.

Moeck, I., Uhlig, S., Loske, B., Jentsch, A., Ferreiro Mählmann, R. \& Stephan, H. 2015: Fossil Multiphase Normal Faults-Prime Targets for Geothermal Drilling in the Bavarian Molasse Basin? - Proceedings, World Geeothermal Congress 2015, 7 p.

Ottlik, P., GÁlfi, J., Horváth, F., Korim, K. \& Stegena, L. 1982: The Low Enthalpy Geothermal Resource of the Pannonian Basin. In: Rybach, L. \& Muffler, P. (eds): Geothermal Systems — Principles and Case Histories. John Wiley \&Sons, Chichester, 359 p.

Pfiffner, O. A. 1986: Evolution of the north Alpine foreland basin in the Central Alps. - Special Publications of International Association of Sedimentologists 8, 219-228.

RYBACH, L. 1992: Geothermal potential of the Swiss Molasse Basin. - Eclogae Geologicae Helvetiae 85, 733-744.

RYBACH, L. 2003: Geothermal Energy — Sustainability and the Environment. — Geothermics 32, 463-470. https://doi.org/10.1016/ S0375-6505(03)00057-9

RYBACH, L. 2010: The "Future of Geothermal Energy" and its challenges. — Proceedings, World Geothermal Congress 2010, 4 p.

RYBACH, L. 2012a: Geothermal Heat Pumps. — In: SAYIGH, A. (ed.): Comprehensive Renewable Energy 7, Oxford, Elsevier, $187-205$.

RYBACH, L. 2012b: New developments in geothermal heat pumps - with a view to the Swiss Success Story. — Proceedings, Japan International Geothermal Symposium, Fukuoka. p. 5973. https://doi.org/10.11367/grsj.35.35

RYBACH, L. 2015: Classification of geothermal resources by potential. — Geothermal Energy Science 3, 1-5. https://doi.org/10.5194/ gtes-3-13-2015

Rybach, L. \& SAnner, B. 2017: Geothermal Heat Pump Development Trends and Achievements in Europe. - In: BerTANI, R. (ed.): Perspectives for Geothermal Energy in Europe. — Imperial College Press, London, 215-253. https://doi.org/10.1142/ 9781786342324_0008

Rybach, L., Bodmer, P., Pavoni, N. \& Mueller, S. 1978: Siting criteria for heat extraction from hot dry rocks: Application to Switzerland. - Pure and Applied Geophysics 116, 1211-1224.

SFOE 2015: Energy Strategy 2050. — In: https://www.bfe.admin.ch/bfe/en/home/policy/energy-strategy-2050.html

SFFO 2019: Electricity statistics. — In: https:/www.bfe.admin.ch/bfe/en/home/supply/statistics-and-geodata/energy-statistics/ electricity-statistics.html 
Shipilin, V., TANner, D.C., Moeck, I. \& Hartmann, H. 2019: Facies and structural interpretation of 3D seismic data in a foreland basin: A case study of the geothermal prospects of Wofratshausen. - Geothermische Energie 91, 24-25.

Signorelli, S. \& KoHL, T. 2006: Geothermische Ressourcenatlas der Nordschweiz — Gebiet des nördlichen Schweizer Mittellandes. — Beiträge zur Geologie der Schweiz, Serie Geophysik 39, 94 p.

Siler, D., FAulds, J. \& Hinz, N. 2015: Regional and Local Geothermal Potential Evaluation: Examples from the Great Basin, USA, Iceland and East Africa. - Proceedings, World Geothermal Congress 2015, $10 \mathrm{p}$.

Tester, J., Anderson, B. J., Batchelor, A. S., Blackwell, D. D., DiPippo, R., Drake, E. M., Livesay, B., Moore, M. C., Nichols, K., PetTy, S., ToKsÖZ, M. N. \& VeAtch, JR., R. W. 2006: The Future of Geothermal Energy —Impact of Enhanced Geothermal Systems (EGS) on the United States in the 21 st Century. - MIT Massachusetts Institute of Technology, Cambridge, $358 \mathrm{p}$.

TóтH, J. 2009: Gravitational Systems of Groundwater Flow. — Cambridge University Press, New York, 297 p.

TótH, J. \& ALMÁSI, I. 2001: Interpretation of observed fluid potential patterns in a deep sedimentary basin under tectonic compression: Hungarian Great Plain, Pannonian Basin. — Geofluids 1, 11-36. https://doi.org/10.1046/j.1468-8123.2001.11004.x

Ungemach , P., Piemonte, C., Antics, M. \& Promis, M. P. 2014: A Reservoir Engineering Approach of Low Enthalpy Geothermal Hear Reclamation. - Geothermal Resources Council Transactions 38, 927-937.

Ungemach, P. \& Antics, M. 2015: Assessment of Deep Seated Geothermal Reservoirs in Selected Sedimentary Environments. Proceedings, World Geothermal Congress 2015, 15 p.

Vernier, R., Laplaige, P., Desplan, A. \& Boissavy, C. 2015: France Country Update. — Proceedings, World Geothermal Congress 2015, 8 p.

Weber, J., Ganz, V., Schellschmidt, R., Sanner, B. \& Schulz, R. 2015: Geothermal Energy Use in Germany. — Proceedings, World Geothermal Congress 2015, 15 p.

Manuscript recieved: 30/04/2019 